Check for updates

Cite this: RSC Adv., 2019, 9, 33794

Received 16th August 2019

Accepted 10th October 2019

DOI: $10.1039 / c 9 r a 06420 f$

rsc.li/rsc-advances

\section{Synthesis and biological evaluation of 3-nitro-4- chromanone derivatives as potential antiproliferative agents for castration-resistant prostate cancer $\dagger$}

\author{
Huiqing Chen, $\dot{+}^{\mathrm{a}}$ Yajing Xing, $\stackrel{+}{\mathrm{b}}^{\mathrm{b}} \mathrm{Jia}$ Xie, ${ }^{\mathrm{b}}$ Jiuqing Xie, ${ }^{\mathrm{b}}$ Dong Xing, ${ }^{\mathrm{D}}{ }^{\mathrm{a}} \mathrm{Jie}$ Tang, ${ }^{\mathrm{a}}$ \\ Fan Yang, (D) Zhengfang Yi ${ }^{* b}$ and Wen-Wei Qiu (D) *a
}

\begin{abstract}
A series of novel 3-nitro-4-chromanones were synthesized and their in vitro cytotoxicity was evaluated on castration-resistant prostate cancer cell (CRPC) lines using the sulforhodamine B (SRB) assay. The amide derivatives showed more potent antitumor activity than their corresponding ester derivatives. Most of the tested compounds showed less toxicity towards human fibroblasts (HAF) compared with the tumor cell lines. The optimal compound 36 possessed much more potent antiproliferative activity than the positive compound cisplatin. The colony formation, cell cycle distribution, apoptosis, transwell migration and wound healing assays of 36 were performed on CRPC cell lines.
\end{abstract}

\section{Introduction}

Prostate cancer (PC) is a type of malignancy that arises in the prostate gland and it tends to develop in older men. Globally, prostate cancer is the second most common cancer among men. The International Agency for Research on Cancer (IARC) estimated 1.27 million new PC cases and 359000 deaths in 2018 worldwide. ${ }^{1}$ Although various anti-cancer agents are used solely or in combination with radiotherapy to treat advanced diseases, none of the conventional therapies have been proven to be highly successful for PC. ${ }^{2}$ It often finally develops into fatal castration-resistant prostate cancer (CRPC) with the ability to grow in the absence of androgens. ${ }^{3}$ CRPC is not responsive to hormonal therapy, readily re-emerges and is highly metastatic, resulting in most of the deaths in PC patients. ${ }^{4}$ The presence of androgen receptor (AR)-negative cell populations in CRPC has been identified and new therapeutic strategies targeting ARnegative PC cells would provide a potential approach for treatment of CRPC. ${ }^{5}$ The AR-negative metastatic DU145 and PC3 cell lines $^{6}$ are often studied as in vitro models for CRPC. ${ }^{7}$ Studies disclosed that 3-nitro-4-chromanones possessed anticancer

${ }^{a}$ Shanghai Engineering Research Center of Molecular Therapeutics and New Drug Development, School of Chemistry and Molecular Engineering, East China Normal University, Shanghai, 200062, China.E-mail: wwqiu@chem.ecnu.edu.cn

${ }^{b}$ Shanghai Key Laboratory of Regulatory Biology, Institute of Biomedical Sciences and School of Life Sciences, East China Normal University, Shanghai, 200241, China. E-mail: zfyi@bio.ecnu.edu.cn

$\dagger$ Electronic supplementary information (ESI) available:Information regarding materials and methods, characterization data of compounds from this study. See DOI: 10.1039/c9ra06420f

\$ These authors contributed equally to this work. activity against murine leukemia L1210 (Fig. 1, A and B), ${ }^{\mathbf{8}, 9}$ human colon HT-29 (Fig. 1, B) ${ }^{9}$ and human acute myeloid leukemia U937 cell line (Fig. 1, C). ${ }^{\mathbf{1 0}}$ Our previous research discovered that 3-nitro-4-chromanone derivatives (Fig. 1, D), especially compound $\mathbf{1}$ (Table 1 ) exhibited as potent antiproliferative activity as cisplatin against CRPC-like DU145 and PC3 cell lines. ${ }^{11}$ Herein, we have evaluated the antiproliferative activity of these newly synthesized 3-nitro-4-chromanones in DU145, PC3 and its more metastatic derivative PC3M cell lines ${ }^{\mathbf{1 2}}$ and disclosed the preliminary structure-activity relationships (SAR) of these compounds. Further investigations including colony formation, cell cycle distribution, apoptosis and migration have also been performed.

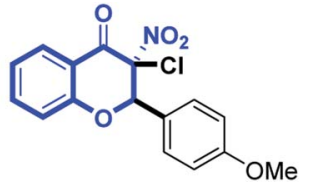

A

$I_{50}=9 \mu \mathrm{M}$ (leukemia L1210 cells)<smiles>C=CCc1cccc2c1OC(c1ccc(OCc3ccccc3)c(I)c1)C(Cl)([N+](=O)[O-])C2=O</smiles>

$\mathrm{IC}_{50}=10 \mu \mathrm{M}$ (leukemia U937 cells)

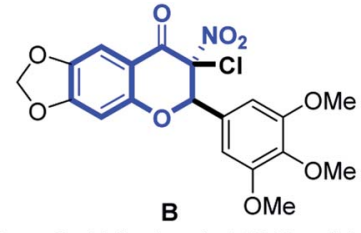

$\mathrm{IC}_{50}=6 \mu \mathrm{M}$ (leukemia L1210 cells) $\mathrm{IC}_{50}=9.8 \mu \mathrm{M}$ (colon HT-29 cells)

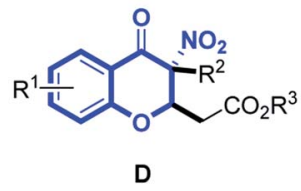

$1 \mathrm{C}_{50}$ values up to $2.54 \mu \mathrm{M}$ against prostate DU145 and PC3 cells

Fig. 1 Structures of reported antitumor 3-nitro-4-chromanones. 
Table $1 \quad I C_{50}$ values of 3-nitro-4-chromanones against the growth of prostate cancer cell lines ${ }^{a}$

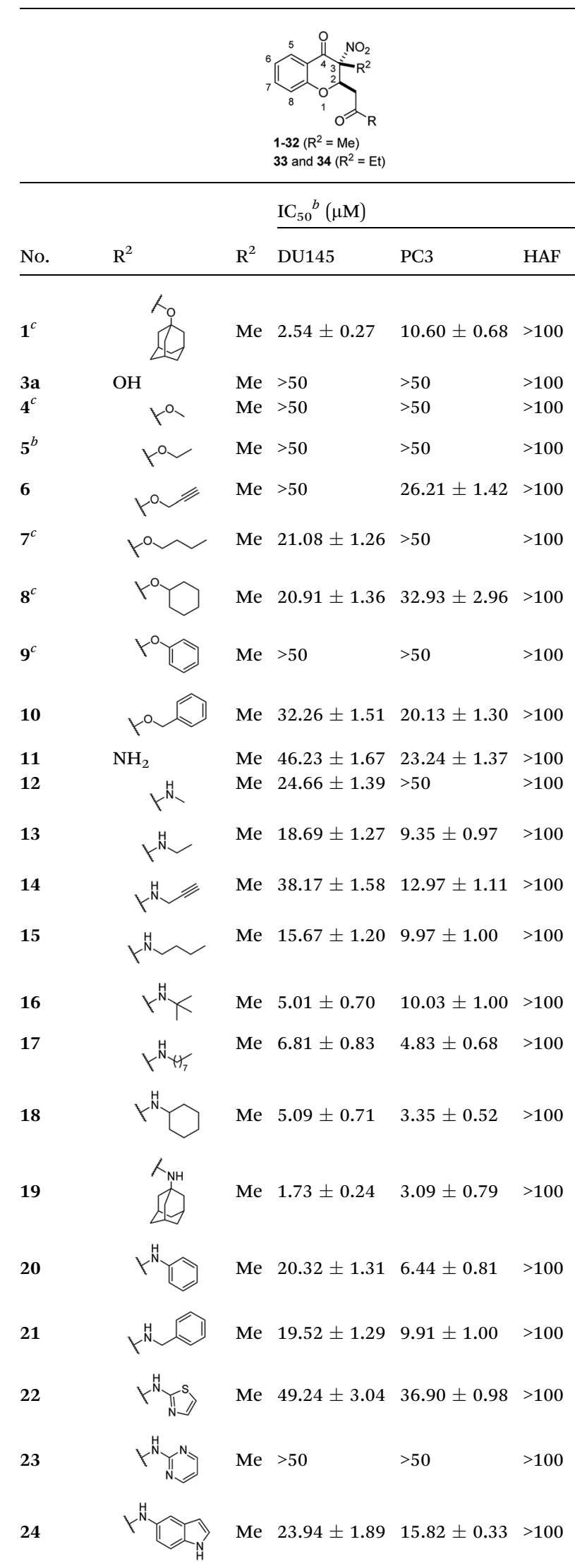

Table 1 (Contd.)

32 (10)

\section{Results and discussion}

\section{Chemistry}

The general strategies developed for compounds synthesis is described as follows (Scheme 1). The esters 2, previously synthesized in our group, were used as starting compounds. Hydrolysis of the esters 2 with $6 \mathrm{~N} \mathrm{HCl}$ in $\mathrm{H}_{2} \mathrm{O} / 1$,4-dioxane to provide the corresponding acids 3. Afterwards, ester compounds 6 and 10 were obtained by condensation of 3 with corresponding alcohols under thionyl chloride. Amide compounds 11-43 were obtained by condensation of 3 with corresponding amines under 1-ethyl-3-(3dimethylaminopropyl) carbodiimide (EDCI), 1- 
hydroxybenzotriazole (HOBt) and $N, N$-diisopropylethylamine (DIPEA) in $\mathrm{CH}_{2} \mathrm{Cl}_{2}$. Compound $\mathbf{4 4}$ was obtained by reduction of the nitro group of compound 36. Structures were well characterized with ${ }^{1} \mathrm{H}$ NMR, ${ }^{13} \mathrm{C}$ NMR and high-resolution mass spectrum.

\section{Biological activities}

Antiproliferative activity. To evaluate the antiproliferative activity of the first-round synthetic 3-nitro-4-chromanones, compounds 1-34 (Table 1) were screened using the SRB assay in AR-negative PC cell lines (DU145 and PC3).

For the carboxylic acid (3a) and its ester compounds (4-10), the results showed that most compounds exhibiting moderate to weak antitumor activity. The carboxylic acid and ester compounds bearing small substituents (4 and 5) possessed almost no activity. The antiproliferative activity was increased to moderate as the small ester group was replaced by relatively large ester substituents (8 and 10), except phenyl ester group (9).

For C-2 amide compounds, they showed obviously improved $\mathrm{IC}_{50}$ values than their corresponding ester compounds (19, 12, 13, 14, 15, 18, 20 and 21 vs. 1, 4, 5, 6, 7, 8, 9 and 10). For alkyl amides, the antiproliferative activity was improved as the substituents increased from small amino $\left(11, \mathrm{IC}_{50}=46.23\right.$ and $23.24 \mu \mathrm{M})$ and aminomethyl $\left(\mathbf{1 2}, \mathrm{IC}_{50}=24.66\right.$ and $\left.>50 \mu \mathrm{M}\right)$ to large $n$-octylamine $\left(17, \mathrm{IC}_{50}=6.81\right.$ and $\left.4.83 \mu \mathrm{M}\right)$ and especially cyclohexane $\left(18, \mathrm{IC}_{50}=5.09\right.$ and $\left.3.35 \mu \mathrm{M}\right)$ and adamantanamine $\left(19, \mathrm{IC}_{50}=1.73\right.$ and $\left.3.09 \mu \mathrm{M}\right)$ groups. For aryl amides, the phenyl amide (20) and benzyl amide (21) showed moderate antitumor activity, and most aromatic heterocyclic amides (2226) showed moderate to weak or even no activity. Therefore, the aryl amide substituents were unfavorable substituted groups for improving antitumor activity. The cyclohexyl amide (18) and adamantane amide (19) were key structures for maintaining the potent antitumor activity. So, we further synthesized the derivatives $(\mathbf{2 7}, \mathbf{2 9 - 3 4})$ based on the compounds 18 and 19. For the derivatives 27, 29-31 and $\mathbf{3 4}$ (the C-3 methyl group was replaced by ethyl group), their antitumor activity, especially in PC3 cells, decreased significantly compared with $\mathbf{1 8}$. The trialkylamines 27 and 28 showed the decreased activity, which means the acidic proton for amide derivative can be essential for the activity. For the derivatives $\mathbf{3 2}$ and $\mathbf{3 3}$ (the C-3 methyl group was replaced by ethyl group), the antitumor activity also decreased obviously compared with 19 . In Table 1 , the most potent compound 19, which bearing an adamantane amide substituent, possessed 1.6-fold (in DU145 cells) and 5.9-fold (in PC3 cells) more potent antiproliferative activity than the positive compound cisplatin. These results illustrated that the adamantane amide group showed more potent activity than other amide groups.

The second-round synthetic compounds $\mathbf{3 5 - 4 4}$ were obtained by modification of the benzene ring of compound 19 and their antiproliferative activity was screened using the SRB assay in DU145, PC3 and PC3M cell lines (Table 2). Results discovered that most compounds possessed moderate to potent antitumor activity, except 44. Most compounds displayed almost no toxicity on human fibroblasts (HAF), except 38. We introduced

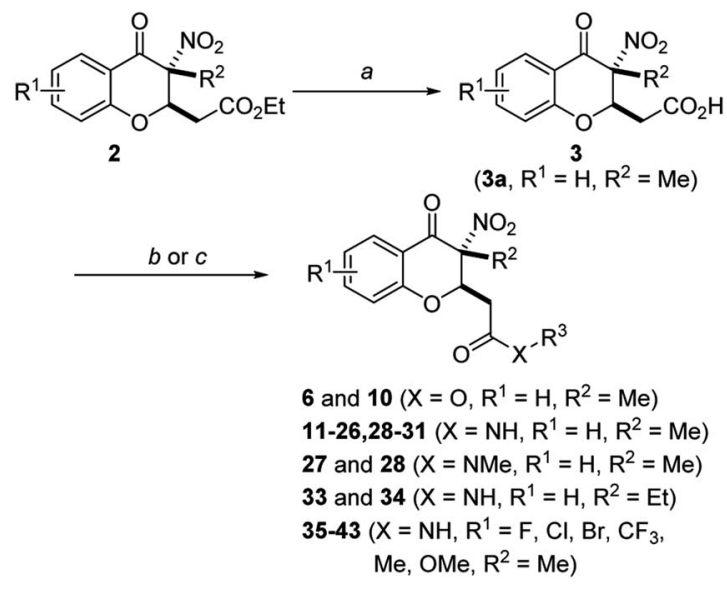

Scheme 1 General synthetic route of compound 3-43. Reagent and conditions: (a) $6 \mathrm{~N} \mathrm{HCl} / 1,4$-dioxane, $100{ }^{\circ} \mathrm{C}, 95 \%$ for 3a; (b) alcohols, $\mathrm{SOCl}_{2}$, 1,4-dioxane, $70{ }^{\circ} \mathrm{C}, 68-81 \%$; (c) amines, HOBt, EDCl, DIPEA, DCM, rt, 64-88\%.

groups $-\mathrm{CF}_{3},-\mathrm{F},-\mathrm{Cl},-\mathrm{Br},-\mathrm{Me}$ and $-\mathrm{OMe}$ into the $\mathrm{C}-6$ position of the benzene ring of 19 firstly. The electron withdrawing $-\mathrm{CF}_{3}$ (35), $-\mathrm{F}$ (36), $-\mathrm{Cl}$ (37) and $-\mathrm{Br}$ (38) groups were favorable substituted groups for improving antitumor activity, except the compound 35 on PC3M cells. The electron donating -Me (39) and -OMe (40) groups decreased the antitumor activity obviously compared with 19. Compound 38 possessed the most potent antiproliferative activity $\left(\mathrm{IC}_{50}\right.$ values were about $\left.0.5 \mu \mathrm{M}\right)$ in DU145, PC3 and PC3M cells, while it also displayed potent toxicity on HAF cells $\left(\mathrm{IC}_{50}=3.67 \mu \mathrm{M}\right)$. The second-best active compound 36 (bearing 6-F group), which $\mathrm{IC}_{50}$ on $\mathrm{HAF}$ was more than $100 \mu \mathrm{M}$. So, 36 and its $-\mathrm{F}$ group was regarded as the optimal compound and substituent. The $-\mathrm{F}$ group was also introduced into the C-5 (41), C-7 (42) and C-8 (43) positions of the benzene ring of 19 and their antitumor activity was decreased slightly compared with $\mathbf{3 6}$. If the nitro group was reduction to amino group at $\mathrm{C}-3$ position of 36 , the antitumor activity was significantly decreased $\left(\mathrm{IC}_{50}>50 \mu \mathrm{M}\right)$. We have also tested the activity of compound 36 on AR-positive prostate cancer cell lines $\mathrm{LNCaP}\left(\mathrm{IC}_{50}=4.4 \mu \mathrm{M}\right)$ and $22 \mathrm{RV} 1\left(\mathrm{IC}_{50}=7.43\right.$ $\mu \mathrm{M})$, which were much weaker than on AR-negative prostate cancer cell lines DU145 $\left(\mathrm{IC}_{50}=1.21 \mu \mathrm{M}\right)$ and PC3 $\left(\mathrm{IC}_{50}=0.94\right.$ $\mu \mathrm{M})$.

Accordingly, although the antitumor activity of compound 36 was much weaker than the positive compound docetaxel, it was 2.3-19.4 times more potent than the positive compound cisplatin and displayed almost no toxicity on normal cells, thus it was selected for further evaluation.

Selective cytotoxicity towards cancer cells. The major challenge in the development of novel anticancer compounds is their selectivity towards cancer cells. All these synthetic compounds were chosen for selectivity test in human skin fibroblast (HAF) cells. The results (Tables 1 and 2) revealed that most of the tested compounds were almost no toxicity on human fibroblasts. The most potent compound 38 also possessed potent toxicity on HAF cells, which showed poor 
Table $2 \quad I_{50}$ values of 3 -nitro-4-chromanones against the growth of prostate cancer cell lines ${ }^{a}$

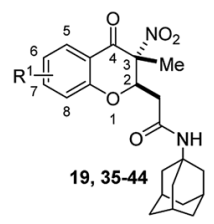

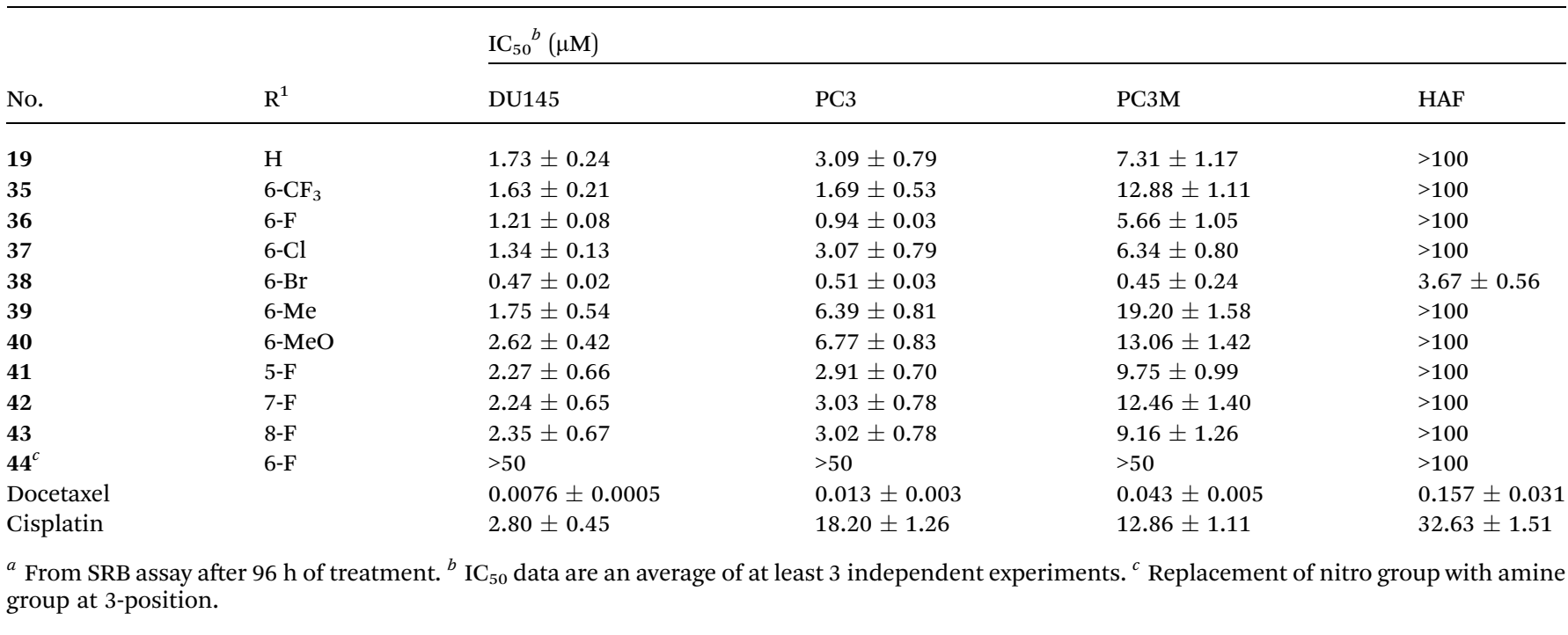

selectivity towards cancer cells. The optimal compound 36 showed up to 106.4 times more selective towards PC3 cells than human fibroblasts which was much better than docetaxel and cisplatin.

Effect on the inhibition of cell colony formation. Colony formation assay not only reveals the proliferation potential of a single cancer cell but also evaluate adaptability of cancer cells to the culture environment. ${ }^{13}$ To further determine the antiproliferation effect of 36, colony formation assay was

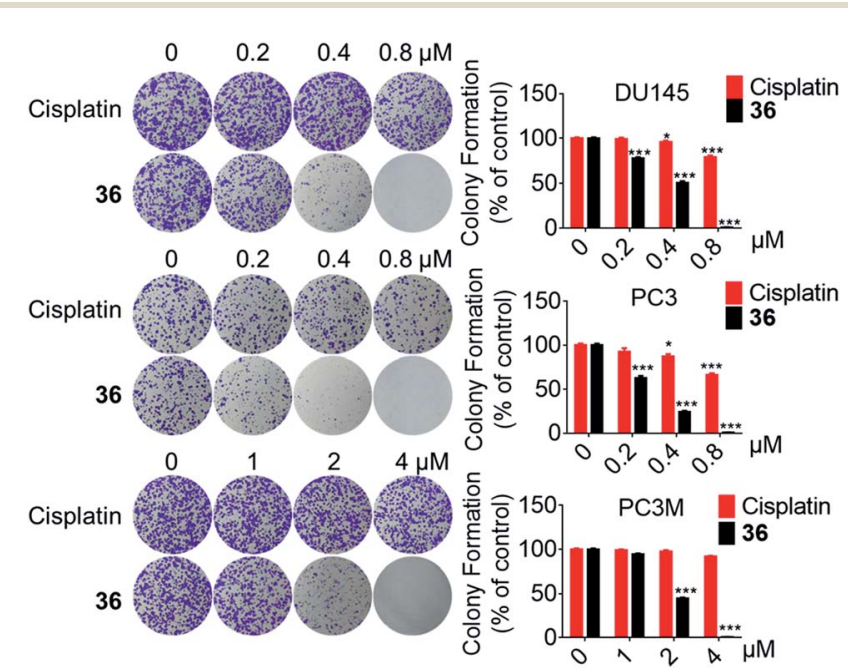

Fig. 2 The colony formation ability of DU145, PC3 and PC3M cells was inhibited by $36 . * p<0.05, * * * p<0.001$. conducted. Colonies were enumerated after 7 days (Fig. 2). Results discovered that $\mathbf{3 6}$ could concentration-dependently inhibit the colony formation in DU145, PC3 and PC3M cell lines. The ability in reduction of colony formation of $\mathbf{3 6}$ was much more potent than the positive compound cisplatin.

Effect on cell cycle distribution of DU145 cells. In order to examine whether the antiproliferative effect of $\mathbf{3 6}$ is associated with cell cycle arrest, ${ }^{14}$ we tested the effect of $\mathbf{3 6}$ on cell cycle distribution using flow cytometry. As shown in Fig. 3, compound 36 concentration-dependently caused the sustained arrest at S phase. After $24 \mathrm{~h}$ of incubation with $10 \mu \mathrm{M}$ of 36, the percentage of $\mathrm{S}$ phase cells increased from $40.57 \%$ to $57.27 \%$,

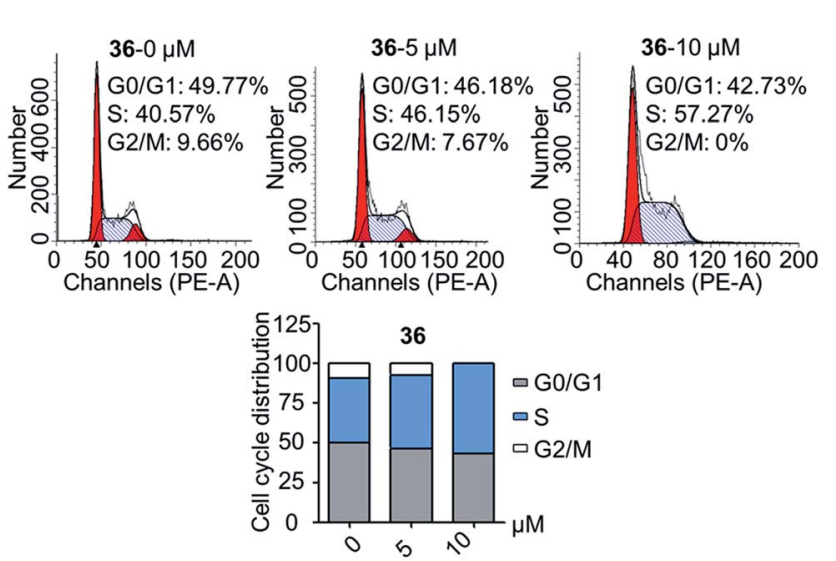

Fig. 3 Compound 36 disrupted the cell cycle distribution of DU145 cells. 
while the cell population in the $\mathrm{G} 2 / \mathrm{M}$ phase decreased from $9.66 \%$ to $0 \%$.

Induction of cell apoptosis. To understand whether compound 36 affected cell viability through inducing cell apoptosis, ${ }^{15}$ apoptosis assay was explored in DU145 cells using flow cytometry. As shown in Fig. 4A, the percentage of apoptotic cells significantly increased from $2.98 \%$ to $25.01 \%$ with doses of 36 increased from 0 to $10 \mu \mathrm{M}$ after $48 \mathrm{~h}$ treatment. The results suggested that this compound inhibited cell proliferation through inducing apoptosis in the cell line mainly.

Western blot analysis. PARP play a key role in cell apoptosis, ${ }^{16}$ thus we also detected the expression of poly ADPribose polymerase (PARP) and Cleaved PARP (CL.PARP) in DU145 cells after 36 treatment. The results showed that 36 dcould promote the PARP to CL. PARP (Fig. 4B) and its induction effect is superior to the apoptosis rate of cisplatin.

Effect on the inhibition of DU145 cell migration. Migration is a key step during the metastasis of cancer. ${ }^{17}$ To determine anti-migration ability of compound 36, transwell migration (Fig. 5A) and wound healing (Fig. 5B) assays were performed. The results showed that $\mathbf{3 6}$ notably prevented migration of DU145 cells in a concentration-dependent manner. The migration rate of 5 and $10 \mu \mathrm{M}$ compound 36 treated DU145 cells was $52.78 \%$ and $23.94 \%$ respectively in comparison with control $(0 \mu \mathrm{M})$.

In conclusion, a series of 3-nitro-4-chromanone derivatives were synthesized by a facile and convenient method. Their antiproliferative activity in CRPC cell lines were assessed in vitro. The amide derivatives showed more potent antitumor activity than their corresponding ester derivatives. Most of these compounds possessed more selectivity towards tumor cells than human fibroblasts. The C-2 adamantane amide and 6-F were favorable substituents for improving antitumor activity. The optimal compound 36, which possessed 2.3-19.4 times more potent than the positive cisplatin in antitumor activity. 36 also displayed more potent than that of cisplatin in colony
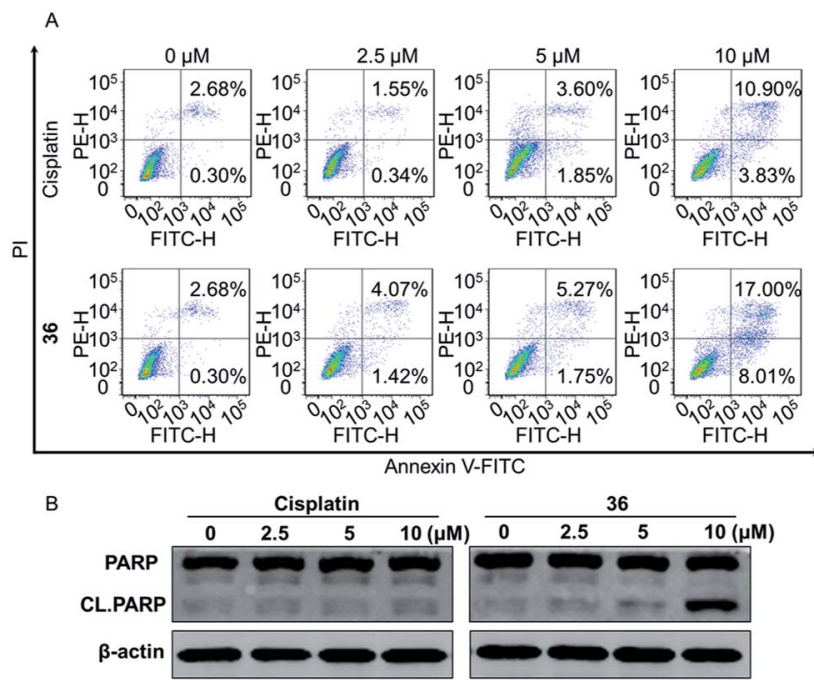

Fig. 4 (A) Compound 36 induced cell apoptosis significantly. (B) The expression of PARP and CL.PARP upon 36 treatment.

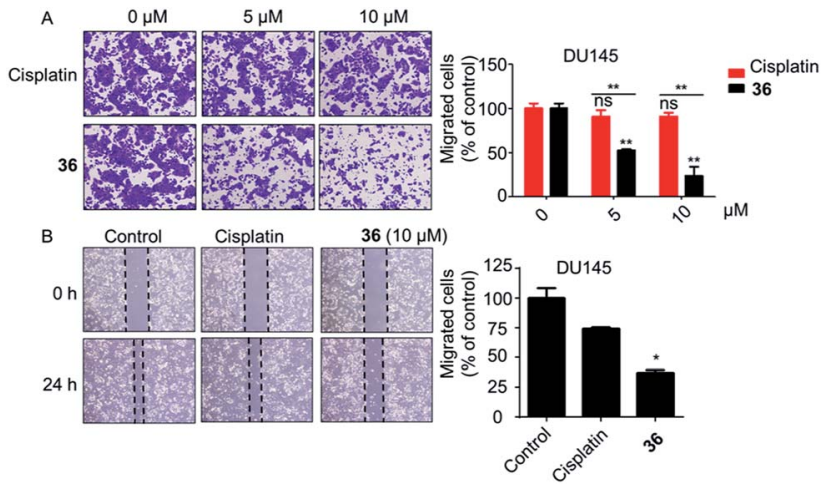

Fig. 5 The cell migration ability of DU145 cells was notably inhibited by 36. (A) Transwell migration assay. (B) Wound healing migration assay (10 $\mu \mathrm{M}$ of 36$) . * p<0.05, * * p<0.01$

formation, apoptosis, transwell migration and wound healing assays. The primary mechanism studies disclosed that $\mathbf{3 6}$ led to $\mathrm{S}$ phase cell cycle arrest and promoted the PARP to CL. PARP in tumor cells. Collectively, we reported 3-nitro-4-chromanone derivatives as a series of new chemical entities for the first time. Especially 36, which displayed potent antitumor activity in CRPC cell lines in vitro, could be used as a promising lead for further development.

\section{Conflicts of interest}

The authors declare no conflicts of interest.

\section{Acknowledgements}

This work was partially supported by Shanghai Science and Technology Council (Grant 18ZR1411200), National Natural Science Foundation of China (21772043) and the Fundamental Research Funds for the Central Universities.

\section{References}

1 (a) F. Bray, J. Ferlay, I. Soerjomataram, R. L. Siegel, L. A. Torre and A. Jemal, Ca-Cancer J. Clin., 2018, 68, 394; (b) C.-C. Weng, P.-Y. Ding, Y.-H. Liu, J. R. Hawse, M. Subramaniam, C.-C. Wu, Y.-C. Lin, C.-Y. Chen, W.-C. Hung and K.-H. Cheng, Oncogene, 2019, 38, 2005; (c) J. Ferlay, M. Colombet, I. Soerjomataram, C. Mathers, D. M. Parkin, M. Piñeros, A. Znaor and F. Bray, Int. J. Cancer, 2019, 144, 1941.

2 (a) G. Attard, C. Parker, R. A. Eeles, F. Schröder, S. A Tomlins, I. Tannock, C. G. Drake and J. S. de Bono, Lancet, 2016, 387, 70; (b) C. Parker, S. Gillessen, A. Heidenreich and A. Horwich, Ann. Oncol., 2015, 26(suppl. 5), v69; (c) T. Wüstemann, U. Haberkorn, J. Babich and W. Mier, Med. Res. Rev., 2019, 39, 40.

3 (a) P. A. Watson, V. K. Arora and C. L. Sawyers, Nat. Rev. Cancer, 2015, 15, 701; (b) Y. Yamamoto, Y. Loriot, E. Beraldi, F. Zhang, A. W. Wyatt, N. Al Nakouzi, F. Mo, T. Y. Zhou, Y. Kim, B. P. Monia, A. R. MacLeod, L. Fazli, 
Y. Z. Wang, C. C. Collins, A. Zoubeidi and M. Gleave, Clin. Cancer Res., 2015, 21, 1675; (c) J. W. Russo, C. Gao, S. S. Bhasin, O. S. Voznesensky, C. Calagua, S. Arai, P. S. Nelson, B. Montgomery, E. A. Mostaghel, E. Corey, M.-E. Taplin, H. H. Ye, M. Bhasin and S. P. Balk, Cancer Res., 2018, 78, 6354.

4 (a) T. A. Yap, A. D. Smith, R. Ferraldeschi, B. Al-Lazikani, P. Workman and J. S. de Bono, Nat. Rev. Drug Discovery, 2016, 5, 699; (b) Y. Zong and A. S. Goldstein, Nat. Rev. Urol., 2013, 10, 90; (c) A. Davies, V. Conteduca, A. Zoubeidi and H. Beltran, European Urology Focus, 2019, 5, 147.

5 C. Tran, S. Ouk, N. J. Clegg, Y. Chen, P. A. Watson, V. Arora, J. Wongvipat, P. M. Smith-Jones, D. Yoo, A. Kwon, T. Wasielewska, D. Welsbie, C. Degui Chen, C. S. Higano, T. M. Beer, D. T. Hung, H. I. Scher, M. E. Jung and C. L. Sawyers, Science, 2009, 324, 787.

6 A. van Bokhoven, M. Varella-Garcia, C. Korch, W. U. Johannes, E. E. Smith, H. L. Miller, S. K. Nordeen, G. J. Miller and M. S. Lucia, Prostate, 2005, 57, 205.

7 (a) T.-C. Shih, R. W. Liu, C.-T. Wu, X. C. Li, W. W. Xiao, X. J. Deng, S. Kiss, T. Wang, X.-J. Chen, R. Carney, H.-J. Kung, Y. Duan, P. M. Ghosh and K. S. Lam, Clin. Cancer Res., 2015, 21, 1675; (b) M. Recagni, M. L. Greco, A. Milelli, A. Minarini, N. Zaffaroni, M. Folini and C. Sissi, Eur. J. Med. Chem., 2019, 177, 401.

8 D. Dauzonne, B. Folléas, L. Martinez and G. G. Chabot, Eur. J. Med. Chem., 1997, 32, 71.

9 A. G. de Peredo, S. Léonce, C. Monneret and D. Dauzonne, Chem. Pharm. Bull., 1998, 46, 79.

10 S. Bouchet, M. Piedfer, S. Susin, D. Dauzonne and B. Bauvois, AIMS Mol. Sci., 2016, 3, 368.
11 H. Q. Chen, J. Xie, D. Xing, J. P. Wang, J. Tang, Z. F. Yi, F. Xia, W.-W. Qiu and F. Yang, Org. Biomol. Chem., 2019, 17, 1062.

12 Z. Y. Xu, Y. L. Wang, Z. G. Xiao, C. Zou, X. Zhang, Z. Wang, D. L. Wu, S. Yu and F. L. Chan, Oncogene, 2018, 37, 6259.

13 (a) Y.-Y. Wang, Y. He, L.-F. Yang, S.-H. Peng, X.-L. He, J.-H. Wang, F. Lv, Y. Hao, M.-Y. Liu, Z. F. Yi and W.-W. Qiu, Eur. J. Med. Chem., 2016, 120, 13; (b) B. Yu, H. Y. Liu, X. Y. Kong, X. L. Chen and C. L. Wu, Eur. J. Med. Chem., 2019, 163, 500.

14 Y. Ai, Y. Hu, F. H. Kang, Y. S. Lai, Y. J. Jia, Z. J. Huang, S. X. Peng, H. Ji, J. D. Tian and Y. H. Zhang, J. Med. Chem., 2015, 58, 4506.

15 A. Valentini, F. Conforti, A. Crispini, A. De Martino, R. Condello, C. Stellitano, G. Rotilio, M. Ghedini, G. Federici, S. Bernardini and D. Pucci, J. Med. Chem., 2009, 52, 484.

16 (a) L. Virág, A. Robaszkiewicz, J. M. Rodriguez-Vargas and F. J. Oliver, Mol. Asp. Med., 2013, 34, 1153; (b) F. J. Oliver, G. de la Rubia, V. Rolli, M. C. Ruiz-Ruiz, G. de Murcia and J. M. -de Murcia, J. Biol. Chem., 1998, 273, 33533; (c) A. Nagarsenkar, L. Guntuku, S. D. Guggilapu, D. Bai K., S. Gannoju, V. G. M. Naidu and N. B. Bathini, Eur. J. Med. Chem., 2016, 124, 782.

17 (a) N. P. Kumar, P. Sharma, T. S. Reddy, S. Nekkanti, N. Shankaraiah, G. Lalita, S. Sujanakumari, S. K. Bhargava, V. G. M. Naidu and A. Kamal, Eur. J. Med. Chem., 2017, 127, 305; (b) D. J. Fu, L. Zhang, J. Song, R. W. Mao, R. H. Zhao, Y. C. Liu, Y. H. Hou, J. H. Li, J. J. Yang, C. Y. Jin, P. Li, X. L. Zi, H. M. Liu, S. Y. Zhang and Y. B. Zhang, Eur. J. Med. Chem., 2017, 127, 87. 